\title{
DETERMINANTS OF FOREIGN DIRECT INVESTMENT FLOWS TO DEVELOPING COUNTRIES: A CROSS-SECTIONAL ANALYSIS
}

\author{
Erdal Demirhan, Mahmut Masca*
}

\begin{abstract}
:
The aim of this paper is to explore, by estimating a cross-sectional econometric model, the determining factors of foreign direct investment (FDI) inflows in developing countries over the period of 2000-2004. The study is based on a sample of cross-sectional data on 38 developing countries. We have used average value of all data for the 2000-2004 period. In the models, dependent variable is FDI. Independent variables are growth rate of per capita GDP, inflation rate, telephone main lines per 1,000 people measured in logs, labour cost per worker in manufacturing industry measured in logs, degree of openness, risk and corporate top tax rate. According to the econometric results, in the main model, growth rate of per capita, telephone main lines and degree of openness have positive sign and are statistically significant. Inflation rate and tax rate present negative sign and are statistically significant. Labour cost has positive sign and risk has negative sign. However, both are not significant.
\end{abstract}

Keywords: determinants of FDI; FDI flows; developing countries; cross-sectional analysis

JEL classification: C21, F21, F23

\section{Introduction}

One of the economic problems of developing countries is that they do not have enough national savings to finance their investments. They are in constant need of foreign capital in forms of both direct and indirect investments. Initially, they took loans from international commercial banks. But in the 1980s the drying-up of commercial bank lending, because of debt crises, forced many countries to reform their investment policies so as to attract more stable forms of foreign capital, and FDI appeared to be one of the easiest way to get foreign capital without undertaking any risks linked to the debt. Thus, it became an attractive alternative to bank loans as a source of capital inflows.

Agiomirgianakis et al. (2003) mentioned that FDI is mostly defined as capital flows resulting from the behaviour of multinational companies (MNCs). Thus, the factors to affect the behaviour of MNCs may also affect the magnitude and the direction of FDI. MNCs expand their activities to a foreign country for a number of reasons including,

* Afyon Kocatepe University, Faculty of Economics and Administrative Sciences, Afyonkarahisar, Turkey (demirhan@aku.edu.tr, mmasca@aku.edu.tr). 
among others, the exploitation of economies of scale/scope, the use of specific advantages, often owing to a life-cycle pattern of their products or just because their competitors are engaged in similar activities. On the other hand, governments are also engaged in a policy competition by changing key factors of their economic policies, such as domestic labour market conditions, corporate taxes, tariff barriers, subsides, privatization and regulatory regime polices so as to improve FDI activity in their countries.

In the Asian Development Outlook (ADB, 2004), it is stated that in recent years FDI has substantially accelerated as a result of many factors, such as rapid technological progress, emergence of globally integrated production and marketing networks, existence of bilateral investment treaties, recommendations from multilateral development banks, and positive evidence from developing countries that have opened their doors to FDI.

Today, as mentioned in Bouoiyour (2003), many countries have been actively trying to attract foreign investment offering income tax holidays, import duty exemptions and subsidies to foreign firms, as well as measures like market preferences, infrastructures and sometimes even monopoly rights.

This paper is organized as follows. Section 2 explains the theoretical framework of FDI. Section 3 gives empirical evidence of earlier studies on the determinants of FDI. Model, data and econometric methodology are described in Section 4. Section 5 explains the econometric results. Finally, we conclude.

\section{The Determinants of FDI: Theoretical Background}

There are many theories which attempt to explain the determinants of FDI. These theories are significant steps towards the development of a systematic framework for the emergence of FDI. However, the capacity of each to serve as a self contained general theory, which could explain all types of FDI (i.e., outward as well as inward FDI at the firm, industry, and country level), has been questioned in the works of various scholars. Agarwal (1980), Parry (1985), Itaki (1991) can be given as examples.

Dunning is one of the most referenced one by authors working on FDI. Dunning (1993) describes three main types of FDI based on the motive behind the investment from the perspective of the investing firm. The first type of FDI is called market-seeking FDI, whose aim is to serve local and regional markets. It is also called horizontal FDI, as it involves replication of production facilities in the host country. Tariff-jumping or export-substituting FDI is a variant of this type of FDI. Because the reason for horizontal FDI is to better serve a local market by local production, market size and market growth of the host economy play important roles. Obstacles to accessing local markets, such as tariffs and transport costs, also encourage this type of FDI. A second type of FDI is called resource-seeking: when firms invest abroad to obtain resources not available in the home country, such as natural resources, raw materials, or low-cost labour. Particularly in the manufacturing sector, when multinationals directly invest in order to export, factor-cost considerations become important. In contrast to horizontal FDI, vertical or export-oriented FDI involves relocating parts of the production chain to the host country. Availability of low-cost labour is a prime driver for export-oriented FDI. Naturally, FDI in the resource sector, such as oil and natural gas, is attracted to 
countries with plentiful natural endowments. The third type of FDI, called efficiency-seeking, takes place when the firm can gain from the common governance of geographically dispersed activities in the presence of economies of scale and scope.

In 1998, the World Investment Report, UNCTAD (1998) has analysed the determinants of FDI and host country determinants have been classified into the three groups. These are politic factors, business facilitation and economic factors.

The absence of a generally accepted theoretical framework has led researchers to rely on empirical evidence for explaining the emergence of FDI.

\section{The Determinants of FDI: Empirical Evidence}

The literature examines a large number of variables that have been set forth to explain FDI. Some of these variables are included in formal hypotheses or theories of FDI, whereas others are suggested because they make sense instinctively. Most of the variables used in empirical studies appear in the UNCTAD's (1998) classification of the determinants of inward FDI.

Regardless of the underlying hypothesis or the classification of these variables, existing empirical studies have considered different combinations of these variables with mixed results, not only with respect to the importance or otherwise of these variables (statistical significance) but in terms of the direction of the effect.

In the literature, there are many determinants often cited in the econometric studies. In the following headlines, some of the determinants and their relations to FDI will be explained in the light of earlier studies.

\section{Market Size}

Artige and Nicolini (2005) state that market size as measured by GDP or GDP per capita seems to be the most robust FDI determinant in econometric studies. This is the main determinant for horizontal FDI. It is irrelevant for vertical FDI. Jordaan (2004) mentions that FDI will move to countries with larger and expanding markets and greater purchasing power, where firms can potentially receive a higher return on their capital and by implication receive higher profit from their investments.

Charkrabarti (2001) states that the market-size hypothesis supports an idea that a large market is required for efficient utilization of resources and exploitation of economies of scale: as the market-size grows to some critical value, FDI will start to increase thereafter with its further expansion. This hypothesis has been quite popular and a variable representing the size of the host country market has come out as an explanatory variable in nearly all empirical studies on the determinants of FDI.

In ODI (1997), it is stated that econometric studies comparing a cross section of countries point to a well-established correlation between FDI and the size of the market, which is a proxy for the size of GDP, as well as some of its characteristics, such as average income levels and growth rates. Some studies found GDP growth rate to be a significant explanatory variable, whereas GDP was not, probably indicating that where the current size of national income is very small, increases may have less relevance to FDI decisions than growth performance, as an indicator of market potential. 
Econometric results on market size are far from being unanimous. Edwards (1990) and Jaspersen et al. (2000) use the inverse of income per capita as a proxy for the return on capital and conclude that real GDP per capita is inversely related to FDI/GDP, but Schneider and Frey (1985), Tsai (1994) and Asiedu (2002) find a positive relationship between the two variables. They argue that a higher GDP per capita implies better prospects for FDI in the host country. Pärletun (2008) finds that the variable GDP is positive and statistically significant at less than $1 \%$ level. She argues that the enlargement of market size tends to stimulate the attraction of FDI to the economy. Ang (2008) finds that real GDP has a significant positive impact on FDI inflows. He also finds that growth rate of GDP exerts a small positive impact on inward FDI.

\section{Openness}

Charkrabarti (2001) states that there is mixed evidence concerning the significance of openness, which is measured mostly by the ratio of exports plus imports to GDP, in determining FDI, as well. The maintained hypothesis is: given that most investment projects are directed towards the tradable sector, a country's degree of openness to international trade should be a relevant factor in the decision.

Jordaan (2004) claims, that the impact of openness on FDI depends on the type of investment. When investments are market-seeking, trade restrictions (and therefore less openness) can have a positive impact on FDI. The reason stems from the "tariff jumping" hypothesis, which argues that foreign firms that seek to serve local markets may decide to set up subsidiaries in the host country if it is difficult to import their products to the country. In contrast, multinational firms engaged in export-oriented investments may prefer to invest in a more open economy since increased imperfections that accompany trade protection generally imply higher transaction costs associated with exporting. Wheeler and Mody (1992) observe a strong positive support for the hypothesis in the manufacturing sector, but a weak negative link in the electronic sector. Kravis and Lipsey (1982), Culem (1988), Edwards (1990) find a strong positive effect of openness on FDI and Schmitz and Bieri (1972) obtain a weak positive link. Pärletun (2008) finds that trade openness is positive but statistically significant from zero.

In ODI (1997), it is stated that while access to specific markets - judged by their size and growth - is important, domestic market factors are predictably much less relevant in export-oriented foreign firms. A range of surveys suggests a widespread perception that "open" economies encourage more foreign investment.

\section{Labour Costs and Productivity}

Charkrabarti (2001) claims that wage as an indicator of labour cost has been the most contentious of all the potential determinants of FDI. Theoretically, the importance of cheap labour in attracting multinationals is agreed upon by the proponents of the dependency hypothesis as well as those of the modernization hypothesis, though with very different implications. There is, however, no unanimity even among the comparatively small number of studies that have explored the role of wage in affecting FDI: results range from higher host country wages discouraging inbound FDI to having no significant effect or even a positive association. 
There is no unanimity in the studies regarding the role of wages in attracting FDI. Goldsbrough (1979), Saunders (1982), Flamm (1984), Schneider and Frey (1985), Culem (1988), and Shamsuddin (1994) demonstrate that higher wages discourage FDI. Tsai (1994) obtains strong support for the cheap-labour hypothesis over the period 1983 to 1986 , but weak support from 1975 to 1978 .

In ODI (1997), it is stated that empirical research has also found relative labour costs to be statistically significant, particularly for foreign investment in labour-intensive industries and for export-oriented subsidiaries. However, when the cost of labour is relatively insignificant (when wage rates vary little from country to country), the skills of the labour force are expected to have an impact on decisions about FDI location.

\section{Political Risk}

The ranking of political risk among FDI determinants remains rather unclear. According to ODI (1997), where the host country owns rich natural resources, no further incentive may be required, as it is seen in politically unstable countries, such as Nigeria and Angola, where high returns in the extractive industries seem to compensate for political instability. In general, as long as the foreign company is confident of being able to operate profitably without excessive risk to its capital and personnel, it will continue to invest. For example, large mining companies overcome some of the political risks by investing in their own infrastructure maintenance and their own security forces. Moreover, these companies are limited neither by small local markets nor by exchange-rate risks since they tend to sell almost exclusively on the international market at hard currency prices.

Specific proxy variables (e.g. number of strikes and riots, work days lost, etc.) have proved significant in some studies; but these quantitative estimates can capture only some aspects of the qualitative nature of political risk.

Empirical relationship between political instability and FDI flows is unclear. For example, Jaspersen et al. (2000) and Hausmann and Fernandez-Arias (2000) find no relationship between FDI flows and political risk while Schneider and Frey (1985) find an inverse relationship between the two variables. Using data on U.S. FDI for two time periods, Loree and Guisinger (1995) found that political risk had a negative impact on FDI in 1982 but no effect in 1977. Edwards (1990) uses two indices, namely political instability and political violence, to measure political risk. Political instability (which measures the probability of a change of government) was found to be significant, while political violence (i.e. the frequency of political assassinations, violent riots and politically motivated strikes) was found to be insignificant.

\section{Infrastructure}

Infrastructure covers many dimensions ranging from roads, ports, railways and telecommunication systems to institutional development (e.g. accounting, legal services, etc.). According to ODI (1997), poor infrastructure can be seen, however, as both an obstacle and an opportunity for foreign investment. For the majority of 
low-income countries, it is often cited as one of the major constraints. But foreign investors also point to the potential for attracting significant FDI if host governments permit more substantial foreign participation in the infrastructure sector.

Jordaan (2004) claims that good quality and well-developed infrastructure increases the productivity potential of investments in a country and therefore stimulates FDI flows towards the country. According to Asiedu (2002) and Ancharaz (2003), the number of telephones per 1,000 inhabitants is a standard measurement in the literature for infrastructure development. However, according to Asiedu (2002), this measure falls short, because it only captures the availability and not the reliability of the infrastructure. Furthermore, it only includes fixed-line infrastructure and not cellular (mobile) telephones.

\section{Growth}

The role of growth in attracting FDI has also been the subject of controversy. Charkrabarti (2001) states that the growth hypothesis developed by Lim (1983) maintains that a rapidly growing economy provides relatively better opportunities for making profits than the ones growing slowly or not growing at all.

Lunn (1980), Schneider and Frey (1985) and Culem (1988) find a significantly positive effect of growth on FDI, while Tsai (1994) obtains a strong support for the hypothesis over the period 1983 to 1986, but only a weak link from 1975 to 1978 . On the other hand, Nigh (1985) reports a weak positive correlation for the less developed economies and a weak negative correlation for the developed countries. Ancharaz (2003) finds a positive effect with lagged growth for the full sample and for the non-Sub-Saharan African countries, but an insignificant effect for the Sub-Saharan Africa sample. Gastanaga et al. (1998) and Schneider and Frey (1985) found positive significant effects of growth on FDI.

\section{$\operatorname{Tax}$}

The literature remains fairly indecisive regarding whether FDI may be sensitive to tax incentives. Some studies have shown that host country corporate taxes have a significant negative effect on FDI flows. Others have reported that taxes do not have a significant effect on FDI. Hartman (1994), Grubert and Mutti (1991), Hines and Rice (1994), Loree and Guisinger (1995), Cassou (1997) and Kemsley (1998) find that host country corporate income taxes have a significant negative effect on attracting FDI flows. However, Root and Ahmed (1979), Lim (1983), Wheeler and Mody (1992), Jackson and Markowski (1995), Yulin and Reed (1995) and Porcano and Price (1996) conclude that taxes do not have a significant effect on FDI. Swenson (1994) reports a positive correlation.

The direction of the effects of above mentioned determinants on FDI may be different. A variable may affect FDI both positively and negatively. For example, factors, such as labour costs, trade barriers, trade balance, exchange rate and tax have been found to have both negative and positive effects on FDI. In the empirical studies a various combination of these determinants as explanatory variables have been used. 
Moosa (2005) states that due to the absence of a consensus on a theoretical framework to guide empirical work on FDI, there is no widely accepted set of explanatory variables that can be regarded as the "true" determinants of FDI.

\section{Data, Methodology and the Model}

The empirical analysis in this study is based on a sample of cross-sectional data on 38 developing countries. List of countries has been indicated in Appendix 1. The relationship between FDI and its determinants is estimated by regressing the following equation.

$$
f d i=\alpha_{0}+\alpha_{1} \text { gro }+\alpha_{2} \text { inf }+\alpha_{3} \log \operatorname{cost}+\alpha_{4} \log t e l+\alpha_{5} \text { op }+\alpha_{6} \text { risk }+\alpha_{7} \operatorname{tax}+\varepsilon
$$

where $f d i$ denotes FDI net inflows as a percentage of Gross Domestic Product (GDP); gro denotes growth rate of per capita GDP, which is a proxy for market size; inf denotes the rate of inflation measured by annual percentage change of consumer prices, which is a proxy for economic stability; logtel shows telephone main lines per 1,000 people measured in logs, which is a proxy for infrastructure; logcost which is a proxy for wage denotes labour cost per worker in manufacturing measured in logs, denominated by dollar per year; $o p$ indicates the degree of openness which is computed as the sum of nominal export and import divided by the nominal GDP; risk denotes composite risk rating $(0=$ higest risk to $100=$ lowest $)$; $\operatorname{tax}$ denotes corporate top tax rate.

The expected sign of gro is positive, since the larger market the more opportunities it offers to foreign investors. Foreign investors who want to invest in a foreign country may desire more stable economy for profitability and easy earnings flow, therefore the expected sign of inf is negative. It is considered that cost advantages have attracted foreign investors. Hence, the expected sign of cost is negative. Foreign investors may prefer countries with better infrastructure. Hereby the expected sign of logtel is positive. Since foreign investors may prefer countries with a liberal trade regime, the expected sign of $o p$ is positive. The expected sign of tax is negative by reason of decreasing profits that occurs due to an increase of tax rates that discourages FDI.

Besides the main model (Model I), we get some models which have alternative degree of openness measurements. The degree of openness has been computed as nominal export divided by the nominal GDP, which is denominated by op 2 in the Model II and Model IV. Another degree of openness indicator has been calculated as nominal import divided by the nominal GDP, which is denominated op 3 in the Model II and Model IV. In order to investigate the effect of market size on FDI, we have used alternative proxies for market size. Loggdpper is included in the main model, denoting reel GDP per capita measured in logs (Model VI). We have also regressed the equation including the reel GDP in $\operatorname{logs}$ denominated by $\log g d p$. Table 1 is showing the variables used in the models and their explanations. 
Variables Used in the Models and Their Explanations

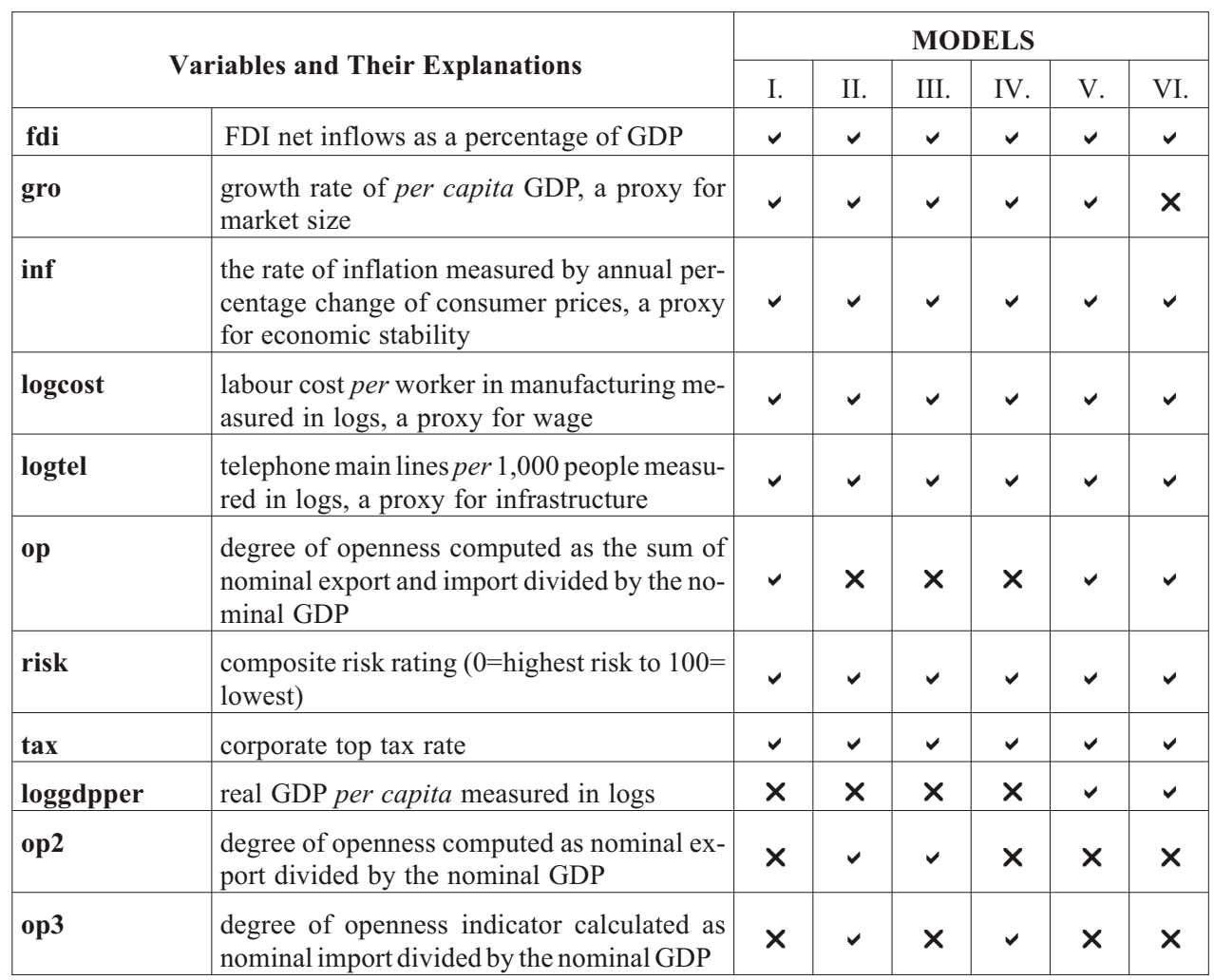

Note: $\checkmark$ included in the model, $\times$ not included in the model

We have used average value of all data for the 2000-2004 period in the cross-section estimations. Definitions and sources for all the main variables are provided in Appendix 2. The data used include 38 countries over the period of 2000 and 2004. We have selected these countries and these time period due to the fact, that some of the variables are not available for most countries. Especially cost data are not available for all countries. All data except for tax rate used in estimations are taken from or calculated based on the World Bank Development Indicators 2004 CD-ROOM. Tax rate is taken from the World Tax Database. Descriptive statistics about variables used in the main model are reported in Appendix 3. Correlation coefficients between variables are shown in Appendix 4.

\section{Econometric Results}

The results of the regression are presented in the Table 2. Empirical results presented in Table 2 support theoretical predictions of the model. These results show that coefficients on gro, logtel and op are positive and significant in the main model. The coefficient on logcost is positive but not significant. The coefficient on inf and tax is 
negative and significant, whereas the coefficient on risk is negative but insignificant. These results show that in case of growth rate of per capita GDP is taken as a proxy for market size, market size can be considered one of the factors that affect FDI.

Table 2

Determinants of FDI, Economic Results

\begin{tabular}{|c|c|c|c|c|c|c|}
\hline & Model I. & Model II. & Model III. & Model IV. & Model V. & Model VI. \\
\hline gro & $\begin{array}{c}0.2804 * \\
(2.0178)\end{array}$ & $\begin{array}{r}0.1734 \\
(1.214) \\
\end{array}$ & $\begin{array}{c}0.2388^{*} \\
(1.7163)\end{array}$ & $\begin{array}{c}0.2575^{*} \\
(1.7670)\end{array}$ & $\begin{array}{r}0.2388 \\
(1.6254)\end{array}$ & \\
\hline inf & $\begin{array}{c}-0.0523 * \\
(-2.0299) \\
\end{array}$ & $\begin{array}{r}-0.0318 \\
(-1.1939) \\
\end{array}$ & $\begin{array}{c}-0.0442^{*} \\
(-1.7083) \\
\end{array}$ & $\begin{array}{c}-0.0483 * \\
(-1.7872) \\
\end{array}$ & $\begin{array}{c}-0.0519^{*} \\
(-2.0077) \\
\end{array}$ & $\begin{array}{r}-0.0426 \\
(-1.6449) \\
\end{array}$ \\
\hline $\log \cos t$ & $\begin{array}{c}0.0542 \\
(0.2246)\end{array}$ & $\begin{array}{r}0.0075 \\
(0.0321) \\
\end{array}$ & $\begin{array}{r}-0.0124 \\
(-0.0520) \\
\end{array}$ & $\begin{array}{r}-0.0402 \\
(-0.1628) \\
\end{array}$ & $\begin{array}{r}0.0261 \\
(0.1068) \\
\end{array}$ & $\begin{array}{r}-0.1175 \\
(-0.5030) \\
\end{array}$ \\
\hline logtel & $\begin{array}{c}0.9244^{* *} \\
(2.5612)\end{array}$ & $\begin{array}{r}0.6333 \\
(1.6482) \\
\end{array}$ & $\begin{array}{c}0.8461^{* *} \\
(2.3149)\end{array}$ & $\begin{array}{l}0.9268^{* *} \\
(2.4303)\end{array}$ & $\begin{array}{c}0.8932 * * \\
(2.4554) \\
\end{array}$ & $\begin{array}{c}0.7137^{*} \\
(2.0051)\end{array}$ \\
\hline op & $\begin{array}{c}0.0179 * \\
(1.8824)\end{array}$ & & & & $\begin{array}{c}0.0174 * \\
(1.8176)\end{array}$ & $\begin{array}{r}0.0150 \\
(1.5463) \\
\end{array}$ \\
\hline risk & $\begin{array}{r}-0.0713 \\
(-0.8886) \\
\end{array}$ & $\begin{array}{r}-0.0013 \\
(-0.0165) \\
\end{array}$ & $\begin{array}{r}-0.0407 \\
(-0.5271) \\
\end{array}$ & $\begin{array}{r}-0.0364 \\
(-0.4395) \\
\end{array}$ & $\begin{array}{r}-0.0668 \\
(-0.8284) \\
\end{array}$ & $\begin{array}{r}-0.0144 \\
(-0.1893) \\
\end{array}$ \\
\hline $\operatorname{tax}$ & $\begin{array}{l}-0.0810^{* *} \\
(-2.1535) \\
\end{array}$ & $\begin{array}{c}-0.0998^{* *} \\
(-2.5179)\end{array}$ & $\begin{array}{c}-0.0797 * * \\
(-2.0877) \\
\end{array}$ & $\begin{array}{c}-0.0799 * \\
(-1.9532)\end{array}$ & $\begin{array}{l}-0.0857 * * \\
(-2.2487) \\
\end{array}$ & $\begin{array}{l}-0.1012 * * \\
(-2.6711)\end{array}$ \\
\hline intercept & $\begin{array}{r}4.7268 \\
(0.9739) \\
\end{array}$ & $\begin{array}{r}2.6676 \\
(0.5554) \\
\end{array}$ & $\begin{array}{r}3.6049 \\
(0.7409) \\
\end{array}$ & $\begin{array}{r}3.7969 \\
(0.7501) \\
\end{array}$ & $\begin{array}{r}3.3857 \\
(0.6648) \\
\end{array}$ & $\begin{array}{r}1.8016 \\
(0.3509) \\
\end{array}$ \\
\hline loggdpper & & & & & $\begin{array}{r}0.2320 \\
(0.8982) \\
\end{array}$ & $\begin{array}{r}0.3645 \\
(1.4476) \\
\end{array}$ \\
\hline op2 & & $\begin{array}{c}0.0855^{* *} \\
(2.1727)\end{array}$ & $\begin{array}{r}0.0337 \\
(1.6818) \\
\end{array}$ & & & \\
\hline op3 & & $\begin{array}{r}-0.0564 \\
(-1.5186) \\
\end{array}$ & & $\begin{array}{r}0.0136 \\
(0.6915) \\
\end{array}$ & & \\
\hline $\begin{array}{l}\text { Heteroske- } \\
\text { dasticity } \\
\text { Test (Pro.) }\end{array}$ & 0.68 & 0.59 & 0.53 & 0.87 & 0.83 & 0.90 \\
\hline Adj. $R^{2}$ & 0.49 & 0.50 & 0.48 & 0.44 & 0.49 & 0.46 \\
\hline F statistic & 6.08 & 5.61 & 5.83 & 5.11 & 5.37 & 5.46 \\
\hline Obser. & 38 & 38 & 38 & 38 & 38 & 38 \\
\hline
\end{tabular}

Note: Numbers in parentheses are $t$ ratios. * and ** denote significance at $10 \%$ and $5 \%$ level, respectively.

This result shows that market size, better infrastructure, trade openness and economic stability have positive effect on FDI. Moreover, low tax rates stimulate FDI. Whether market-size affects FDI or not depends on specification of variables. When we use per capita GDP as a proxy for market size, it is not found any empirical evidence for the effect of market- size on FDI. The same result occurs when absolute GDP is used as a proxy for market size. It must be emphasized that absolute GDP reflects size of 
population rather than income. Therefore, absolute GDP may be considered as a relatively poor indicator of market size. All results about market size obtained from alternative models show that the growth of per capita real GDP affects FDI but per capita real GDP does not. We conclude from the results that foreign investors aiming at making profits prefer growing economies to large economies.

The effect of infrastructure on FDI is positive and significant. This result shows that investors are attracted to a country with better infrastructure. The effect of wage on FDI is negative but not statistically significant. This result suggests that a low wage is not necessarily a crucial factor for FDI. The country risk variable is negative but not significant. This result also indicates that country risk may not be necessarily a critical factor for FDI.

When we include op 2 and op 3 instead of op (Model II), econometric results change remarkably. In this model only tax and op 2 have expected effects on fdi. Model III and Model IV included either op 2 or op 3 show that coefficients on gro, and logtel are positive and significant. The coefficient on logcost is negative but not significant. The coefficients on inf and tax are negative and significant, whereas the coefficient on risk is negative and insignificant. In these models, coefficients on op 2 and $o p 3$ are positive but not significant.

Model V included loggdpper has similar results as compared with Model I. The basic difference between results of Model I and Model V is that growth has positive but not significant effect on FDI in Model V. In this context, Model V shows that growing economy has no positive effect on FDI contrary to Model I. In Model VI, we have omitted gro from Model V. This model analyses whether FDI flows to growing economy or large economy. Model VI shows that large economy has no positive effect on FDI similarly to Model V. According to Model VI, economic stability has no positive effect on FDI. This result differs from the result of Model I. In Model VI, when we use loggdp which is real GDP in logs, the results of the regression are similar to Model VI.

\section{Conclusions}

The objective of this study was to analyse the determinants of foreign direct investment in developing countries. In order to undertake it, we performed an econometric model based on cross-sectional analysis for 38 developing countries over the period of 2000-2004. We have used average value of all data for the 2000-2004 period in the cross-section estimates.

According to our analysis, gro as a proxy for market size, logtel as a proxy for infrastructure and op as a proxy to reflect the willingness of a country to accept foreign investment have positively affected FDI, being significant. We have used growth of per capita real GDP as a proxy for market size, because absolute GDP reflects size of population rather than income. When we use absolute GDP or per capita GDP for market size, we see that they do not affect FDI. We conclude from this result that investors prefer growing economies to large economies.

The coefficient of logtel as a proxy for infrastructure has positive sign and is significant. It means that better infrastructure is an important determinant in attracting FDI to developing countries. 
The coefficient of an economy's degree of openness $(o p)$ as the sum of nominal export and import divided by the nominal GDP has been included as a proxy to reflect the willingness of a country to accept foreign investment. It has presented a positive sign, and is significant. This demonstrates that openness is another important determinant for FDI to developing countries.

Inflation (inf) appears as an indicator of economic stability. It presents a negative sign and is significant in the regressions. It means that low inflation rates have been effective in attracting FDI to developing countries. Tax has also negative sign and is significant. It shows that low tax rates are another important determining factor for FDI to developing countries.

The coefficiant of logcost, which is a proxy for wage, denotes labour cost per worker in manufacturing industry measured in logs, has positive sign but is not significant. The expected sign for logcost was negative. We can conclude from this result that low wage has not been a determining factor in attracting FDI to developing countries in the period we have studied. When wage rates vary little from country to country, the skills of the labour force are expected to have an impact on decisions about FDI location.

The variable risk presents negative sign, but it is not significant. This demonstrates that risk has not been an important factor in attracting FDI in the mentioned period. When the host countries present high returns, firms may ignore political risk. As long as the foreign company is confident of being able to operate profitably without excessive risk to its capital and personnel, it may continue to invest.

\section{References}

ADB (2004), "Asian Development Outlook 2004." http://www.adb.org/Documents/Books/ ADO/2004/default.asp.

Agarwal, J. P. (1980), "Determinants of Foreign Direct Investment: A Survey." Weltwirtschaftliches Archiv, 116, pp. 739-773.

Agiomirgianakis, G., Asteriou, D., \& Papathoma, K. (2003), "The Determinants of Foreign Direct Investment: A Panel Data Study for the OECD Countries." http://www.city. ac.uk/economics/ dps/discussion_papers/0306.pdf.

Ancharaz, V. D. (2003), "Determinants of Trade Policy Reform in Sub-Saharan Africa." Journal of African Economies, 12(3), pp. 417-443.

Ang, J. B. (2008), "Determinants of Foreign Direct Investment in Malaysia." Journal of Policy Modeling, 30 (1), pp. 185-189.

Artige, L., Nicolini, R. (2005), "Evidence on the Determinants of Foreign Direct Investment: The Case of Three European Regions." http://pareto.uab.es/wp/2005/65505.pdf

Asiedu, E. (2002), "On the Determinants of Foreign Direct Investment to Developing Countries: Is Africa Different?" World Development, 30(1), pp. 107-119.

Bouoiyour, J. (2003), "The Determining Factors of Foreign Direct Investment in Morocco." http://www.erf.org.eg/tenthconf/Trade_Background/Bouoiyour.pdf.

Cassou, S. P. (1997), "The Link Between Tax Rates and Foreign Direct Investment." Applied Economics, 29, pp. 1295-1301.

Charkrabarti, A. (2001), "The Determinants of Foreign Direct Investment: Sensitivity Analyses of Cross-Country Regressions." Kyklos, 54(1), pp. 89-114.

Culem, C. G. (1988), "The Locational Determinants of Direct Investment among Industrialized Countries." European Economic Review, 32, pp. 885-904.

Dunning, J. H. (1993), Multinational Enterprises and the Global Economy. Harlow, Essex: Addison Wesley publishing Co.

Edwards, S. (1990), "Capital Flows, Foreign Direct Investment, and Dept - Equity Swaps in Developing Countries" (Working Paper No. 3497 ed.): NBER 
Flamm, K. (1984), "The Volatility of Offshore Investment." Journal of Development Economics, 16, pp. 231-248.

Gastanaga, V. M., Nugent, J. B., Pashamova, B. (1998), "Host Country Reforms and FDI Inflows: How Much Difference Do They Make?" World Development, 26 (7), pp. 1299-1314.

Goldsbrough, D. G. (1979), "The Role of Foreign Direct Investment in the External Adjustment Process." (Staff Papers 26), pp. 725-754.

Grubert, H., Mutti, J. (1991), "Taxes, Tariffs and Transfer Pricing in Multinational Corporate Decision Making." Review of Economic Studies, 73, pp. 285-293.

Hartman, D. G. (1994), "Tax Policy and Foreign Direct Investment in the United States." National Tax Journal, 37 (4), pp. 475-488.

Hausmann, R., Fernandez-Arias, E. (2000), "The New Wave of Capital Inflows: Sea Change or Just Another Title?" (Working Paper No. 417).

Hines, J. R., Rice, E. M. (1994), "Fiscal Paradise: Foreign Tax Havens and American Business." The Quarterly Journal of Economics, 109, pp. 149-182.

Itaki, M. (1991), "A Critical Assessment of the Eclectic Theory of the Multinational Enterprise." Journal of International Business Studies, 25, pp. 445-460.

Jackson, S., Markowski, S. (1995), "The Attractiveness of Countries to Foreign Direct Investment." Journal of World Trade, 29, pp. 159-180.

Jaspersen, F. Z., Aylward, A. H., Knox, A. D. (2000), "The Effects of Risk on Private Investment: Africa Compared with Other Developing Areas," in P. P. Collier, C. (Ed.), Investment and Risk in Africa. New York: St Martin's Press.

Jordaan, J. C. (2004), "Foreign Direct Investment and Neighbouring Influences." Unpublished doctoral thesis, University of Pretoria.

Kemsley, D. (1998), "The Effect of Taxes on Production Location." Journal of Accounting Research, 36, pp. 321-341.

Kravis, I. B., Lipsey, R. E. (1982), "Location of Overseas Production and Production for Exports by U.S. Multinational Firms." Journal of International Economics, 12, pp. 201-223.

Lim, D. (1983), "Fiscal Incentive and Direct Foreign Investment in Less Developed Countries." The Journal of Development Studies, 19, pp. 207- 212.

Loree, D., Guisinger, S. E. (1995), "Policy and Non-Policy Determinants of U.S. Equity Foreign Direct Investment." Journal of International Business Studies, 26, pp. 281-300.

Lunn, J. (1980), "Determinants of U.S. Direct Investment in the E. E. C.: Further Evidence." European Economic Review, 13, pp. 93-101.

Moosa, I. A. (2005), "The Determinants of Foreign Direct Investment in Mena Countries: An Extreme Bounds Analysis." The paper presented at the the 12th Annual Conference of the Economic Research Forum.

Nigh, D. (1985), "The Effect of Political Events on United States Direct Foreign Investment: A Pooled Time-Series Cross-Sectional Analysis." Journal of International Business Studies, 16, pp. 3-17.

ODI (1997), "Foreign Direct Investment Flows to Low-Income Countries: A Review of the Evidence." http://www.odi.org.uk/publications/briefing/3_97.html.

Parry, T. G. (1985), "Internalization as a General Theory of Foreign Investment: A Critique." Weltwirtschaftliches Archiv, 121, pp. 564-569.

Pärletun, J. (2008), "The Determinants of Foreign Direct Investment: A Regional Analysis with Focus on Belarus." http://biblioteket.ehl.lu.se/olle/papers/0002948.pdf

Porcano, T. M., Price, C. E. (1996), "The Effects of Government Tax and Non-Tax Incentives on Foreign Direct Investment." Multinational Business Review, 4, pp. 9-20.

Root, E., Ahmed, A. (1979), "Empirical Determinants of Manufacturing: Direct Foreign Investment Developing Countries." Economic Development and Cultural Change, 27, pp. 758-767.

Saunders, R. S. (1982), "The Determinants of Foreign Direct Investment." Canadian Journal of Economics, 15, pp. 77-84.

Schmitz, A., Bieri, J. (1972), "EEC Tariffs and US Direct Investment." European Economic Review, 3, pp. 259-270.

Schneider, F., Frey, B. (1985), "Economic and Political Determinants of Foreign Direct Investment." World Development, 13(2), pp. 161-175.

Shamsuddin, A. F. (1994), "Economic Determinants of Foreign Direct Investment in Less Developed Countries." The Pakistan Development Review, 33, pp. 41-51. 
Swenson, D. L. (1994), "The Impact of U. S. Tax Reform on Foreign Direct Investment in the United States." Journal of Public Economics, 54, pp. 243-266.

Tsai, P. (1994), "Determinants of Foreign Direct Investment and its Impact on Economic Growth." Journal of Economic Development, 19(1), pp. 137-163

UNCTAD (1998), "World Investment Report (WIR) 1998: Trends and Determinants." New York and Geneva.

Wheeler, D., Mody, A. (1992), "International Investment Location Decisions: The Case for U.S. Firms." Journal of International Economics, 33, pp. 57-76.

Yulin, N., Reed, M. R. (1995), "Locational Determinants of U. S. Direct Foreign Investment in Food and Kindered Products." Agrobusiness, 11, pp. 77- 86.

\section{APPENDICES}

\section{Appendix 1}

\section{List of Countries}

Argentina, Bangladesh, Brazil, Cameron, Chile, China, Colombia, Costa Rica, Czech Republic, Dominican Republic, Ecuador, Egypt, Ethiopia, Guatemala, Honduras, Hungary, India, Jamaica, Jordon, Kenya, Latvia, Mexico, Morocco, Oman, Panama, Paraguay, Philippines, Poland, Romania, Russian Federation, Senegal, South Africa, Sri Lanka, Syrian Arab Republic, Thailand, Tunisia, Turkey, Vietnam

\section{Appendix 2}

\section{Definitions of Variables}

\begin{tabular}{|l|l|}
\hline$f d i$ & Foreign Direct Investment, net inflows (\% of GDP) \\
\hline gro & GDP per capita growth (annual \%) \\
\hline inf & Inflation, consumer prices (annual \%) \\
\hline$t e l$ & Telephone main lines (per 1,000 people) \\
\hline risk & Composite Risk Rating $(0=$ higest risk to $100=$ lowest) \\
\hline op & (Export + Import of goods and services (current \$)/ Current \$ GDP)x100 \\
\hline op2 & (Export of goods and services (current \$)/ Current \$ GDP)x100 \\
\hline op3 & (Import of goods and services (current \$)/ Current \$ GDP)x100 \\
\hline tax & Corporate Top Tax Rate (annual \%) \\
\hline$g d p p e r ~$ & GDP per capita (constant 1995 US \$) \\
\hline gdp & GDP (constant 1995 US \$) \\
\hline cost & Labour cost per worker in manufacturing (\$ per year) \\
\hline & \\
\hline $\begin{array}{l}\text { All data used in the study are taken from the World Bank except for corporate top tax rates. These } \\
\text { rates are available in World Tax Database } \\
\text { (http://www.bus.umich.edu/OTPR/otpr/introduction.htm) }\end{array}$ \\
\hline
\end{tabular}


Appendix 3

Descriptive Statistics

\begin{tabular}{|l|r|r|r|r|r|r|r|r|}
\hline & fdi & gro & inf & logcost & logtel & op & risk & tax \\
\hline Mean & 2.81 & 2.04 & 11.99 & 7.82 & 4.27 & 68.85 & 68.04 & 32.28 \\
\hline Median & 2.71 & 1.74 & 6.83 & 7.89 & 4.52 & 64.39 & 69.08 & 33.27 \\
\hline Maximum & 7.59 & 7.44 & 69.75 & 10.25 & 5.81 & 125.45 & 77.43 & 50.00 \\
\hline Minimum & 0.27 & -1.57 & -0.54 & 4.54 & 1.21 & 21.31 & 54.86 & 17.50 \\
\hline Std. Dev. & 1.92 & 1.95 & 15.79 & 1.06 & 1.19 & 27.90 & 6.03 & 6.85 \\
\hline Skewness & 0.67 & 0.67 & 2.42 & -0.55 & -1.08 & 0.31 & -0.18 & -0.15 \\
\hline Kurtosis & 2.64 & 3.48 & 8.07 & 4.37 & 3.59 & 2.25 & 2.01 & 3.65 \\
\hline Observations & 38 & 38 & 38 & 38 & 38 & 38 & 38 & 38 \\
\hline
\end{tabular}

Note: These statistics are based on averages used in cross-section estimates and refer to common samples. Labour cost per worker in manufacturing (cost) and telephone main lines per 1,000 people are measured in logs, other variables are measured as percentages except composite risk rating (risk).

Appendix 4

\section{Correlation Matrix}

\begin{tabular}{|l|l|l|l|l|l|l|l|l|}
\hline & fdi & gro & inf & logcost & logtel & op & risk & tax \\
\hline fdi & 1 & & & & & & & \\
\hline gro & 0.31 & 1 & & & & & & \\
\hline inf & -0.12 & -0.13 & 1 & & & & & \\
\hline logcost & 0.01 & -0.35 & 0.05 & 1 & & & & \\
\hline logtel & 0.52 & -0.02 & 0.34 & 0.20 & 1 & & & \\
\hline op & 0.44 & 0.11 & -0.11 & -0.16 & 0.28 & 1 & & \\
\hline risk & 0.50 & 0.30 & -0.50 & -0.00 & 0.46 & 0.47 & 1 & \\
\hline tax & -0.49 & -0.13 & -0.21 & -0.10 & -0.43 & -0.15 & -0.13 & 1 \\
\hline
\end{tabular}

Note: See Appendix 3. 